\title{
ERRATUM
}

\section{Predicting utility scores for prostate cancer: mapping the Prostate Cancer Index to the Patient-Oriented Prostate Utility Scale (PORPUS)}

KE Bremner, N Mitsakakis, L Wilson and MD Krahn

Prostate Cancer and Prostatic Disease (2014) 17, 98-104; doi:10.1038/pcan.2013.55

Correction to: Prostate Cancer and Prostatic Diseases (2013) advance online publication 15 October 2013; doi:10.1038/ pcan.2013.44

Following publication of the above article, the authors noticed that Appendixes 1 and 2 were presented incorrectly. Appendix 1 appeared without boxes indicating where selections could be made. The first half of Appendix 2 was repeated, and the second half was omitted. The corrected appendixes appear below. The publisher regrets the errors. 


\section{APPENDIX 1}

UCLA-PROSTATE CANCER INDEX (PCI)

\section{URINARY FUNCTION}

This section is about your urinary habits. Please consider ONLY THE LAST 4 WEEKS.

1. Over the past 4 weeks, how often have you leaked urine?

\begin{tabular}{|c|c|}
\hline Every day $\ldots \ldots \ldots \ldots \ldots \ldots \ldots \ldots \ldots \ldots$ & \\
\hline About once a week ................. & \\
\hline Less than once a week . . . . . . . . . . . . . . . & (Check one \\
\hline Not at all $\ldots \ldots \ldots \ldots \ldots \ldots \ldots \ldots \ldots$ & \\
\hline
\end{tabular}

2. Which of the following best describes your urinary control during the last four weeks?

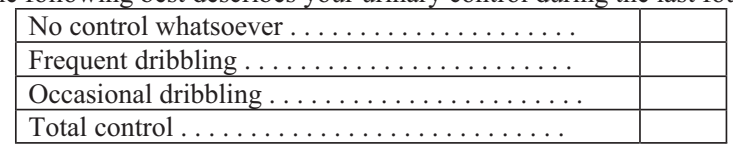

(Check one box)

3. How many pads or adult diapers per day did you usually use to control leakage during the last 4 weeks?

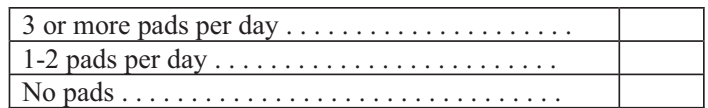

(Check one box)

4. How big a problem, if any, has each of the following been for you? (Check one box on each line)

\begin{tabular}{|c|c|c|c|c|c|}
\hline & $\begin{array}{c}\text { No } \\
\text { Problem } \\
\end{array}$ & $\begin{array}{l}\text { Very Small } \\
\text { Problem }\end{array}$ & $\begin{array}{c}\text { Small } \\
\text { Problem } \\
\end{array}$ & $\begin{array}{l}\text { Moderate } \\
\text { Problem }\end{array}$ & $\begin{array}{c}\text { Big } \\
\text { Problem } \\
\end{array}$ \\
\hline $\begin{array}{l}\text { a. } \begin{array}{l}\text { Dripping urine or wetting } \\
\text { your pants } \ldots \ldots \ldots \ldots\end{array} \\
\end{array}$ & & & & & \\
\hline $\begin{array}{l}\text { b. Urine leakage interfering } \\
\text { with your sexual activity }\end{array}$ & & & & & \\
\hline
\end{tabular}

5. Overall, how big a problem has your urinary function been for you during the last 4 weeks?

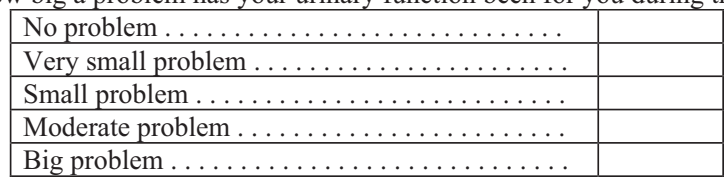

(Check one box) 


\section{BOWEL HABITS}

The next section is about your bowel habits and abdominal pain.

Please consider ONLY THE LAST 4 WEEKS.

6. How often have you had rectal urgency (felt like you had to pass stool, but did not) during the last 4 weeks?

\begin{tabular}{|c|}
\hline More than once a day $\ldots \ldots \ldots \ldots \ldots \ldots$ \\
\hline About once a day $\ldots \ldots \ldots \ldots \ldots \ldots \ldots \ldots$ \\
\hline More than once a week $\ldots \ldots \ldots \ldots \ldots \ldots \ldots$ \\
\hline About once a week . . . . . . . . . . . . . . \\
\hline
\end{tabular}

(Check one box)

7. How often have you had stool (bowel movements) that were loose or liquid (no form, watery, mushy) during the last 4 weeks?

\begin{tabular}{|c|c|}
\hline Never $\ldots \ldots \ldots \ldots \ldots \ldots \ldots \ldots$ & \\
\hline Rarely $\ldots \ldots \ldots \ldots \ldots \ldots \ldots \ldots$ & \\
\hline About half the time $\ldots \ldots \ldots \ldots \ldots \ldots \ldots$ & \\
\hline Usually $\ldots \ldots \ldots \ldots \ldots \ldots \ldots \ldots \ldots$ & \\
\hline Always $\ldots \ldots \ldots \ldots \ldots \ldots \ldots \ldots$ & \\
\hline
\end{tabular}

(Check one box)

8. How much distress have your bowel movements caused you during the last 4 weeks?

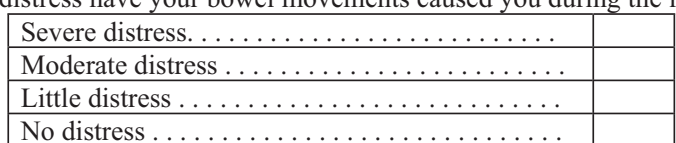

(Check one box)

9. How often have you had crampy pain in your abdomen or pelvis during the last 4 weeks?

\begin{tabular}{|c|c|}
\hline \multicolumn{2}{|l|}{ Several times a day . . . . . . . . . . . . . } \\
\hline About once a day .................... & \\
\hline Several times a week .................. & \\
\hline About once a week . . . . . . . . . . . . . . . & \\
\hline About once this month $\ldots \ldots \ldots \ldots \ldots$ & \\
\hline Rarely or never. & \\
\hline
\end{tabular}

(Check one box)

10. Overall, how big a problem have your bowel habits been for you during the last 4 weeks?

\begin{tabular}{|c|}
\hline$\ldots \ldots \ldots \ldots \ldots \ldots \ldots \ldots$ \\
\hline Moderate problem . . . . . . . . . . . . . . \\
\hline Small problem . . . . . . . . . . . . . . . . . \\
\hline Very small problem $\ldots \ldots \ldots \ldots \ldots \ldots \ldots \ldots$ \\
\hline
\end{tabular}

(Check one box) 


\section{SEXUAL FUNCTION}

The next section is about your sexual function and sexual satisfaction. Many of the questions are very personal, but they will help us understand the important issues that you face every day. Please answer honestly about THE LAST 4 WEEKS ONLY.

11. How would you rate each of the following during the last 4 weeks?

(Check one box on each line)

\begin{tabular}{|l|l|l|l|l|l|}
\hline & $\begin{array}{l}\text { Very } \\
\text { Poor }\end{array}$ & $\underline{\text { Poor }}$ & Fair & Good & $\begin{array}{c}\text { Gery } \\
\text { Good }\end{array}$ \\
\hline a. Your level of sexual desire?........ & & & & & \\
\hline b. Your ability to have an erection?.... & & & & & \\
\hline c. Your ability to reach orgasm (climax)? & & & & & \\
\hline
\end{tabular}

12. How would you describe the QUALITY of your erections?

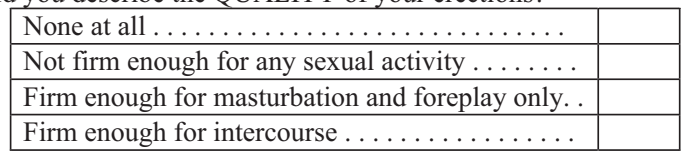

(Check one box)

Firm enough for intercourse .

13. How would you describe the FREQUENCY of your erections?

\begin{tabular}{|c|c|}
\hline I NEVER had an erection when I wanted one. . . . & \\
\hline $\begin{array}{l}\text { I had an erection LESS THAN HALF the times I } \\
\text { wanted one } \ldots \ldots \ldots \ldots \ldots \ldots \ldots \ldots \ldots \ldots\end{array}$ & \\
\hline $\begin{array}{l}\text { I had an erection ABOUT HALF the time I } \\
\text { wanted one } \ldots \ldots \ldots \ldots \ldots \ldots \ldots \ldots \ldots \ldots \ldots\end{array}$ & \\
\hline $\begin{array}{l}\text { I had an erection MORE THAN HALF the time I } \\
\text { wanted one } \ldots \ldots \ldots \ldots \ldots \ldots \ldots \ldots \ldots \ldots\end{array}$ & \\
\hline I had an erection WHENEVER I wanted one. & \\
\hline
\end{tabular}

(Check one box)

I had an erection WHENEVER I wanted one.

14. How often have you awakened in the morning or night with an erection?

Never. . .

Seldom (less than $25 \%$ of the time)

Not often (less than half the time).

Often (more than half the time)

Very often (more than $75 \%$ of the time)

(Check one box)

15. During the last 4 weeks did you have intercourse?

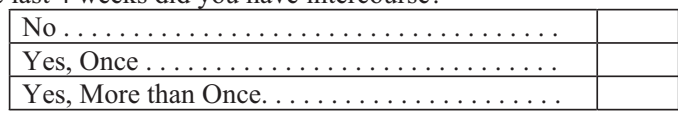

(Check one box)

16. Overall, how would you rate your ability to function sexually during the last 4 weeks?

\begin{tabular}{|c|}
\hline Very poor $\ldots \ldots \ldots \ldots \ldots \ldots \ldots$ \\
\hline 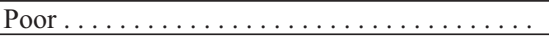 \\
\hline 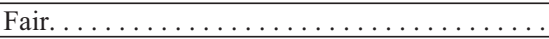 \\
\hline Good $\ldots \ldots \ldots \ldots \ldots \ldots \ldots \ldots \ldots \ldots$ \\
\hline Very $\operatorname{good} \ldots \ldots \ldots \ldots \ldots \ldots \ldots$ \\
\hline
\end{tabular}

(Check one box)

17. Over all, how big a problem has your sexual function been for you during the last 4 weeks?

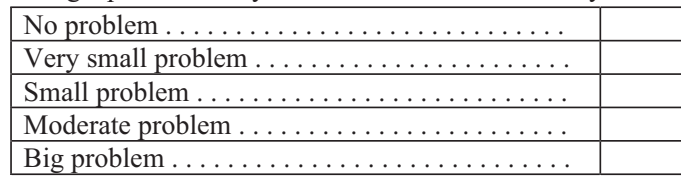

(Check one box) 
PATIENT ORIENTED PROSTATE UTILITY SCALE (PORPUS)

\section{Pain and Disturbing Body Sensations}

(e.g. hot flashes, painful swelling of breasts, nausea)

Please check the statement that comes closest to describing you in the last two weeks

1. No pain and no disturbing body sensations.

2. Mild pain or disturbing body sensations that do not limit any activities (for example: work, social, sexual, sleep).

3. Moderate pain or disturbing body sensations that limit a few activities.

4. Moderate to severe pain or disturbing body sensations that limit some activities.

5. Severe pain or disturbing body sensations that limit many activities.

\section{Energy}

Please check the statement that comes closest to describing you in the last two weeks.

1. Very full of energy, lots of pep.

2. Fairly energetic, no limitation of activities (for example: work, social, sexual).

3. Moderate reduction in energy or pep that limits a few activities.

4. Generally low energy or pep that limits some activities.

5. No energy or pep at all. I feel drained, and many activities are limited.

\section{Support From Family and Friends}

Please check the statement that comes closest to describing you in the last two weeks.

1. Most of the time feel supported by my spouse, family and friends.

2. A fair amount of the time feel supported by my spouse, family and friends.

3. Occasionally feel supported by my spouse, family and friends.

4. Rarely feel supported by my spouse, family, and friends.

\section{Communication With Doctor}

(primary caregiver for prostate cancer, may be specialist or family doctor)

Please check the statement that comes closest to describing you in the last two scheduled appointments

1. Always able to express my concerns to my Doctor and get all the information or advice I need.

2. Most the time, able to express my concerns to my Doctor and get all the information or advice I need.

3. Some of the time, able to express my concerns to my Doctor and get all the information or advice I need.

4. Rarely able to express my concerns to my Doctor and get all the information or advice I need. 


\section{Emotional Well-Being}

Please check the statement that comes closest to describing you in the last two weeks.

1. Generally happy and free from worry, sadness, or frustration.

2. A little worry, sadness, or frustration.

3. Moderate worry, sadness, or frustration.

4. Quite a bit of worry, sadness, or frustration.

5. Extreme worry, sadness, or frustration.

VI. Urinary Frequency (need to pass urine frequently during the day or night)

and Urgency (difficulty delaying urination after the urge is felt to urinate, ability to "hold it")

Please check the statement that comes closest to describing you in the last two weeks.

1. No urinary frequency or urgency.

2. A little urinary frequency or urgency, does not interfere with sleep or other activities (for example: work, social); no need to plan ahead.

3. Some urinary frequency or urgency that interferes with sleep or other activities; may need to plan ahead.

4. Quite a bit of urinary frequency or urgency; need to be near a bathroom most of the time.

5. Extreme urinary frequency or urgency; need to be near a bathroom always.

\section{Leaking Urine/ Poor Bladder Control}

Please check the statement that comes closest to describing you in the last two weeks.

1. Never, under any circumstances leak urine or lose bladder control.

2. On rare occasions, leak urine or lose bladder control, does not interfere with any activities (for example: work, social, sexual, sleep).

3. Occasionally leak urine or lose bladder control, interferes with a few activities.

4. A moderate amount of the time, leak urine or lose bladder control, interferes with some activities.

5. Most of the time, leak urine or have poor bladder control, interferes with many activities.

6. Require a clamp, catheter, or collecting bag because of leaking urine or poor bladder control. 


\section{Sexual Function}

(problems with achieving / maintaining an erection)

Please check the statement that comes closest to describing you in the last two weeks.

1. Full erections sufficient for intercourse.

2. Erections sufficient for intercourse, but some reduction in firmness.

3. Erections sufficient for masturbation or foreplay only.

4. Erections, but not firm enough for any sexual activity.

5. No erections at all.

\section{Sexual Interest / Drive}

Please check the statement that comes closest to describing you in the last two weeks.

1. Normal amount of sexual drive and interest for you.

2. A little decrease of sexual drive or interest for you.

3. Moderate decrease of sexual drive or interest for you.

4. Substantial decrease of sexual drive or interest for you.

5. No sexual drive or interest.

\section{Bowel problems: diarrhea, rectal discomfort (pain, burning or irritation) or constipation.}

Please check the statement that comes closest to describing you in the last two weeks.

1. No diarrhea, rectal discomfort, or constipation.

2. Occasionally have diarrhea, rectal discomfort, or constipation.

3. Frequently have diarrhea, rectal discomfort, or constipation

4. Nearly always have diarrhea, rectal discomfort, or constipation. 